\title{
ANT FAUNA OF ANNUAL AND PERENNIAL CROPS
}

\author{
JeŠOVNIK, A. ${ }^{1,2,3^{*}}$ - BLAŽEVIĆ, I. ${ }^{4}$ - LEMIĆ, D. ${ }^{4}$ - PAJAČ ŽIVKOVIĆ, I. ${ }^{4 *}$ \\ ${ }^{1}$ Ministry of environment and energy, Radnička cesta 80/7, 10000 Zagreb, Croatia \\ ${ }^{2}$ Croatian Myrmecological Society, Gortanova 14, 10000 Zagreb, Croatia \\ ${ }^{3}$ National Museum of Natural History, Smithsonian Institution, Department of Entomology \\ Washington, District of Columbia, United States of America \\ ${ }^{4}$ University of Zagreb, Department of Agricultural Zoology \\ Svetošimunska cesta 25, 10000 Zagreb, Croatia \\ *Corresponding authors \\ e-mail:ana.mrav@gmail.com (Ana Ješovnik),ipajac@agr.hr (Ivana Pajač Živković)
}

(Received $15^{\text {th }}$ Apr 2019; accepted $4^{\text {th }}$ Jul 2019)

\begin{abstract}
Ants (Hymenoptera: Formicidae) are a diverse and abundant part of soil fauna with the ability to maintain and restore soil quality and to increase crop yields in agroecosystems. Some ant species are sensitive to land management, which makes them good bioindicators of soil function in land use management and conservation throughout the world. In Croatia, ants are understudied and they were never sampled on agricultural crops. In this study, we used pitfall traps to collect ants on three different land use types: annual crops, perennial crops, and semi-natural habitats. We found 12 ant species, out of which one species, Tetramorium atratulum (Schenck, 1852), is a new record for Croatia. We observed significantly lower ant abundance on annual crops than on both perennial crops and semi-natural habitats. Similarly, ant richness and diversity were lowest on annual crops, although this difference was not statistically significant. Our results contribute to the increasing evidence that intensive agricultural practices, particularly soil tillage, are detrimental to the arthropod diversity. The transition to sustainable agriculture will require utilizing the ecosystem services of naturally occurring insects, such as ants.
\end{abstract}

Keywords: Formicidae, Tetramorium atratulum, sustainable agriculture, CAP, bioindicators, reduced tillage

\section{Introduction}

Agricultural intensification across Europe has a severe impact on the environment, mainly through pesticide and nitrate pollution, soil erosion, loss of habitats, and simplification of animal and plant communities, all of which leads to the decline and extinction of wildlife (Skinner et al., 1997; Stoate et al., 2001; Schweiger et al., 2005; German et al., 2017). With additional pressures of human population growth and climate change (Piao et al., 2010; Myers et al., 2014) the intensive, industrial-scale crop production has become unsustainable, and the need is recognized for a transition to agroecological farming systems. Traditional farming, organic farming, and conservation agriculture all tend to govern management by ecological principles, to decrease the environmental impact, and to increase the nutritional value of the produced food (Hobbs et al., 2008; Reganold and Wachter, 2016; German et al., 2017). One of the important goals of agroecology is the efficient utilization of ecosystem services of naturally occurring organisms, in particular insects and other invertebrates (Lavelle et al., 2006). This includes using diversity and abundance of soil fauna as indicators of soil quality, integrated pest management, and incorporating agricultural practices that support the 
biodiversity of soil organisms, which are crucial for soil health (Power, 2010; Sanabria et al., 2014; Furlan et al., 2017).

Ants (Hymenoptera: fam. Formicidae) are ubiquitous, diverse, and dominant terrestrial insects (Holldobler and Wilson, 1990). Majority of ant species nest in soil, and have a well-documented impact on its biological, physical, and chemical properties (Stadler et al., 2006; Frouz and Jilková, 2008; Dorn, 2014; Farji-Brener and Werenkraut, 2017). By creating micropores ants aerate the soil and increase its water absorption, bring in minerals and nutrients (Lobry De Bruyn, 1999; Evans et al., 2011), improve soil fertility (Farji-Brener and Werenkraut, 2017), and ant nests are an important resource for other organisms. The vicinity of ant nests has 30 fold higher density of microarthropods, fivefold higher density of protozoa, and significantly higher mineralization rates (Lobry De Bruyn, 1999; Wagner et al., 2004). Large-scale exclusion experiments on ants in agricultural systems show that ants have a positive net influence (up to 50\%) on crop yield, as they increase soil porosity and moisture; nitrogen, carbon and phosphorus content, microorganism biomass, and decrease pest populations (Evans et al., 2011; Wielgoss et al., 2013; Gras et al., 2016; Shukla et al., 2016).

Additionally, ants can be used as bioindicators of soil quality in land management (Read and Andersen, 2000; Andersen et al., 2002; Sanabria et al., 2014). Ants, in general, respond rapidly to environmental changes, they are abundant and easy to sample, and some species have specific ecological requirements (Dufrêne and Legendre, 1997; Lobry De Bruyn, 1999; Underwood and Fisher, 2006; Sanabria et al., 2014). The practice of using ants as tools in land management is more common in tropical and subtropical than in temperate agroecosystems (Dufrêne and Legendre, 1997; Lobry De Bruyn, 1999; Underwood and Fisher, 2006; Sanabria et al., 2014). Several studies in Europe show potential for using ants in land management. In Italy and France ants were good bioindicators of organic farming (Masoni et al., 2017) and environmentally safe soil amendment treatments (Castracani et al., 2015), as well as a useful tool in conservation, e.g. as indicators of restoration processes (Ottonetti et al., 2006).

Ant research has been relatively neglected in Croatia (Bračko, 2006). The national ant survey was never conducted, and collections focus on a series of small scale inventory studies in protected areas (Ješovnik et al., 2011; Ješovnik and Pečarevič, 2018). Ants were never investigated in the context of agricultural habitats in Croatia, unlike other arthropods, e.g., carabid beetles (Lemić et al., 2016, 2017; Pajač Živković et al., 2016). In this study, we investigate ant fauna associated with agricultural habitats in Croatia, determine which species are associated with intensive agriculture, and test whether ant species richness, abundance, diversity, and community composition differ between annual and perennial crops. We predict that agricultural intensity would negatively affect the abundance, richness, and diversity of ants.

\section{Materials and methods}

\section{Study site and data collection}

We conducted the fieldwork in Zagreb, Croatia $\left(45^{\circ} 49^{\prime} \mathrm{N} 15^{\circ} 59^{\prime} \mathrm{E}\right.$, altitude 145 meters), on experimental fields of Faculty of Agriculture and surrounding semi-natural habitats. Zagreb has a temperate continental climate modified by the maritime influence of the Mediterranean and under the local influence of Mount Medvednica (Zaninović et al., 2008). Based on the last comprehensive review of Croatian ants Zagreb has 23 ant species (Bračko, 2006). 
We sampled ants on three plots per each land use type (nine plots total): on annual crops (potato, soy, corn), perennial crops (two apple orchards and vineyard), and on non-agricultural habitats as a control (three semi-natural habitats: meadow, meadow next to the forest edge, park-forest). Each plot was $25 \times 11$ meters in size. The annual crop fields were the most intensive agricultural management regime in our study, with standard and deep soil tillage and pre-planting soil preparation in autumn. The perennial plots represented the intermediate management regime, with no tillage or any other mechanical soil manipulation, and with mowing as only cultivation technique. Both annual and perennial crops had a variable degree of fertilization and insecticide use (details in Table 1). Sampled semi-natural habitats had no soil management regime, no fertilizer was used, and the mowing was the only cultivation regime. Semi-natural habitats were chosen to represent the gradation from open to closed habitats, and to be as natural as possible considering their location in the urban area. All plots were located on the University of Agriculture campus or adjacent to it (Fig. 1).

Table 1. Study plots (Zagreb, Croatia). T-Tillage, F-Fertilizer, I-Insecticide

\begin{tabular}{c|c|c|c|c|c|c|c}
\hline Plot & Land use & Habitat & T & F & I & Latitude & Longitude \\
\hline P1 & control & meadow & - & - & - & 45.826548 & 16.029084 \\
P2 & control & meadow & - & - & - & 45.828077 & 16.028118 \\
P3 & control & park forest & - & - & - & 45.826011 & 16.030004 \\
V1 & perennial & orchard & - & yes & yes & 45.828628 & 16.029201 \\
V2 & perennial & orchard & - & - & - & 45.826138 & 16.028996 \\
VL & perennial & vineyard & - & yes & - & 45.827507 & 16.028881 \\
KR & annual & potato field & standard & yes & yes & 45.829358 & 16.034092 \\
KU & annual & corn field & deep & yes & - & 45.827378 & 16.034005 \\
SO & annual & soy field & standard & yes & - & 45.825106 & 16.032288 \\
\hline
\end{tabular}

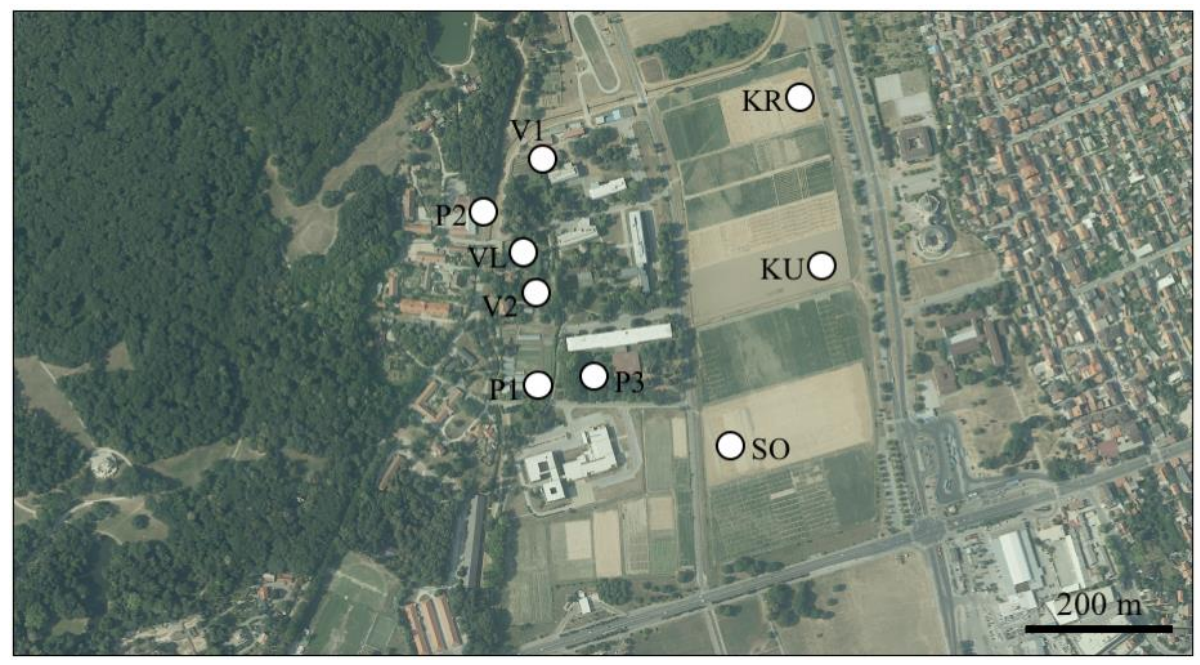

Figure 1. Map with localities of sampling plots (P1, P2, P3 - control; V1, V2, VL-perennial; $K R, K U, S O$ - annual plots) in Zagreb, Croatia

We sampled ants using pitfall traps (100 $\mathrm{mL}$ container, $6 \mathrm{~cm}$ diameter), which are the standard sampling technique of ground-nesting ants (Agosti et al., 2000). We set up 10 pitfall traps per plot, five in each of two parallel rows, with a 4-meter distance between the individual traps, and a minimum of $4.5 \mathrm{~m}$ distance from the plot edge. Pitfall traps 
were filled with 20-25 mL of the mixture of $90 \%$ ethanol, water, glycerol, and detergent. The traps were active for 48 hours, from 12-14 July 2018, after which they were collected, labeled, and ants were sorted into $90 \%$ ethanol. The 48-hour period of trapping is recommended as a standard protocol for the efficient estimate of abundance, occurrence, and community composition of ants (Agosti et al., 2000; Borgelt and New, 2006), and it is frequently used in similar studies (Castracani and Mori, 2006; Ribas et al., 2011; Frizzo and Vasconcelos, 2013).

\section{Data processing and analyses}

We identified collected ants to the species level using taxonomical keys (Agosti and Collingwood, 1987; Seifert, 2007; Wagner et al., 2017) and online resources (antweb.org). Specimens were counted, and at least one representative of each species was pinned and deposited in Croatian myrmecological society collection (HMD, Zagreb, Croatia). Map of the sampling plots was prepared in ESRI GIS ArcMap 10.1 software.

We calculated descriptive statistics, ant species richness (S), diversity (ShannonWeiner's index, H' and Fisher's alpha), and abundance (individual counts per species) for each plot and each land use type. We conducted a one-way analysis of variance (ANOVA) on log-transformed data to compare the effect of agricultural intensity on ant richness, abundance, and diversity in our studied land use types (annual, perennial, and control habitat). When the results of ANOVA were significant, we ran the post hoc Tukey test to calculate the significant difference between individual groups (annual-control, annual-perennial, control-perennial). To investigate the differences in ant community assemblages between the land use types we used non-parametric multidimensional scaling (NMDS) based on pairwise distance (Bray-Curtis dissimilarity) using ant abundance data. We ran all of the analyses and created plots in $\mathrm{R}$ program language $(\mathrm{R}$ Development Core Team, 2014), using packages vegan, ape, picante, and psych. The custom $\mathrm{R}$ code we used is available online from https://github.com/anajesovnik/AgriAnt.

\section{Results}

\section{Comparison of ant communities of different agricultural intensity}

We collected a total of nine ant species in semi-natural habitats, eight on perennial crops, and six species on annual crops. The differences in ant abundances show a similar trend, with 175 individuals collected on semi-natural habitat, 158 on perennial, and 34 on annual crops (Table 2, Fig. 2).

Table 2. Mean ( \pm standard deviation) ant species richness, abundance, and diversity

\begin{tabular}{c|c|c|c}
\hline Land use & Richness & Abundance & Diversity (H') \\
\hline control & $5.67( \pm 0.58)$ & $58.33( \pm 13.65)$ & $1.3( \pm 0.13)$ \\
perennial & $4.67( \pm 1.53)$ & $52.67( \pm 13.65)$ & $1.21( \pm 0.3)$ \\
annual & $2.33( \pm 1.15)$ & $11.33( \pm 9.24)$ & $0.57( \pm 0.52)$ \\
\hline
\end{tabular}

Ant abundance on plots with different agricultural intensity was statistically significantly different (ANOVA $\mathrm{F}_{(2,6)}=13.58, \mathrm{p}=0.00593$ ). The post hoc Tukey test found a significant difference in ant abundance between the annual and control $(\mathrm{p}=0.008)$ and annual and perennial groups $(\mathrm{p}=0.01)$. In contrast, ant richness and ant diversity (Fisher's Alpha) were not significantly different between different land use 
plots (richness: ANOVA $\mathrm{F}_{(2,6)}=4.53, \mathrm{p}=0.0631$; diversity: ANOVA $\mathrm{F}_{(2,6)}=0.568$, $\mathrm{p}=0.594)$, although they showed the same trend: both richness and diversity were decreasing with the increase in agricultural intensification (Table 3). The results of the NMDS analysis (stress value: $0.08, \mathrm{R}^{2}=0.993$ ) show an overlap of ant communities of different land use types (Fig. 3), with no clear clustering of plots based on land use type. One of the annual crop plots (potato field) grouped closer to natural and perennial plots.
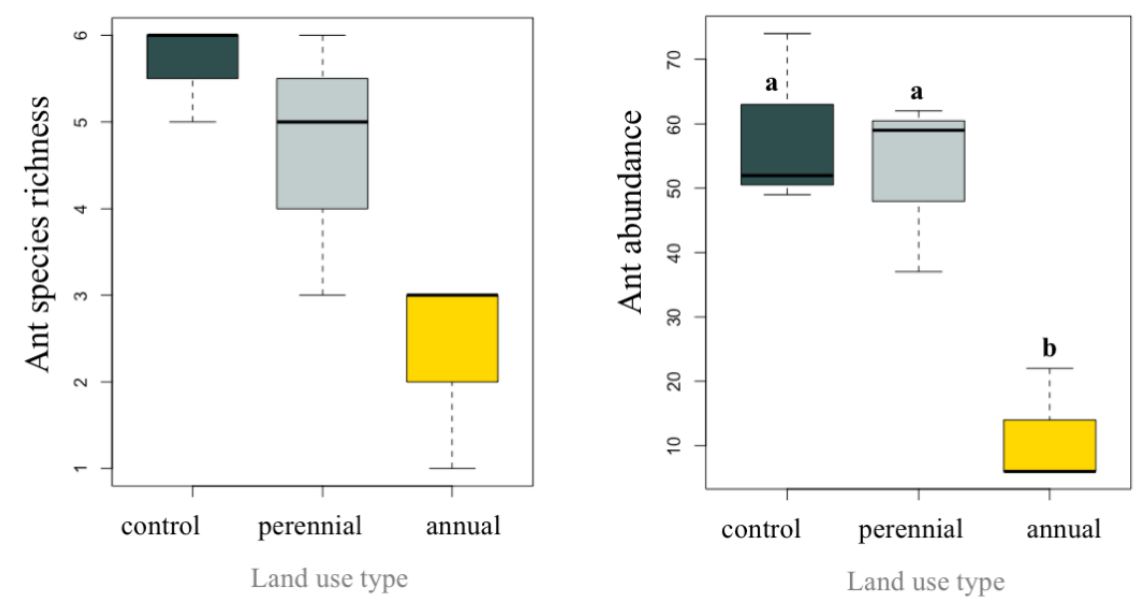

Figure 2. Ant richness and abundance across different land use types. Significant level for post hoc test was 0.05

Table 3. Ant species abundance per plot replicates in different land use types. Species names are followed by the index to species' image in Figure 4

\begin{tabular}{c|c|c|c|c|c|c|c|c|c|c|}
\hline \multirow{2}{*}{ Species } & \multicolumn{3}{|c|}{ control } & \multicolumn{3}{c|}{ perennial } & \multicolumn{3}{c}{ annual } \\
\cline { 2 - 9 } & $\mathrm{P} 1$ & $\mathrm{P} 2$ & $\mathrm{P} 3$ & $\mathrm{~V} 1$ & $\mathrm{~V} 2$ & $\mathrm{VL}$ & $\mathrm{KR}$ & $\mathrm{KU}$ & $\mathrm{SO}$ \\
\hline Ponera coarctata 4h & - & - & - & - & 1 & - & - & - & - \\
Aphaenogaster subterranea 4f & - & - & 21 & - & 3 & - & - & - & - \\
Myrmica scabrinodis 4e & 1 & - & 4 & - & 8 & - & - & - & - \\
Solenopsis fugax 4d & 30 & 14 & 3 & 6 & 5 & 2 & - & - & 3 \\
Tetramorium caespitum 4b & - & 7 & - & 24 & - & 17 & 16 & - & 2 \\
Tetramorium semilaeve 4g & - & 3 & - & - & - & - & - & - & - \\
Tetramorium atratulum 4k & - & - & - & - & - & - & 1 & - & - \\
Formica cunicularia 4a & 2 & 10 & 5 & 7 & 20 & 18 & 5 & - & - \\
Lasius myops 4i & - & - & - & 2 & - & - & - & - & 1 \\
Lasius niger 4c & 8 & 37 & 19 & 23 & 22 & - & - & 6 & - \\
Polyergus rufescens 41 & 1 & 3 & - & - & - & - & - & - & - \\
Tapinoma erraticum 4j & 7 & - & - & - & - & - & - & - & - \\
\hline Total richness & 6 & 6 & 5 & 5 & 6 & 3 & 3 & 1 & 3 \\
Total abundance & 49 & 74 & 52 & 62 & 59 & 37 & 22 & 6 & 6 \\
\hline
\end{tabular}

\section{The composition of ant communities}

During this study, we collected 367 ants, belonging to 12 species within four ant subfamilies and nine genera (Table 3, Fig. 4). Eight of the species (Formica cunicularia Latreille, 1798; Lasius myops Forel, 1894; Ponera coarctata (Latreille, 1802); Tetramorium semilaeve André, 1883; Aphaenogaster subterranea (Latreille, 1798); Myrmica scabrinodis Nylander, 1846; Solenopsis fugax (Latreille, 1798)) are first 
records for Zagreb, which reflects the lack of myrmecological investigations, rather than surprising discoveries. One species, a rare workerless social parasite, Tetramorium atratulum (Schenck, 1852), is a new record for Croatia as well. We collected a single queen of this species, on one of the annual crop plots (potato field).

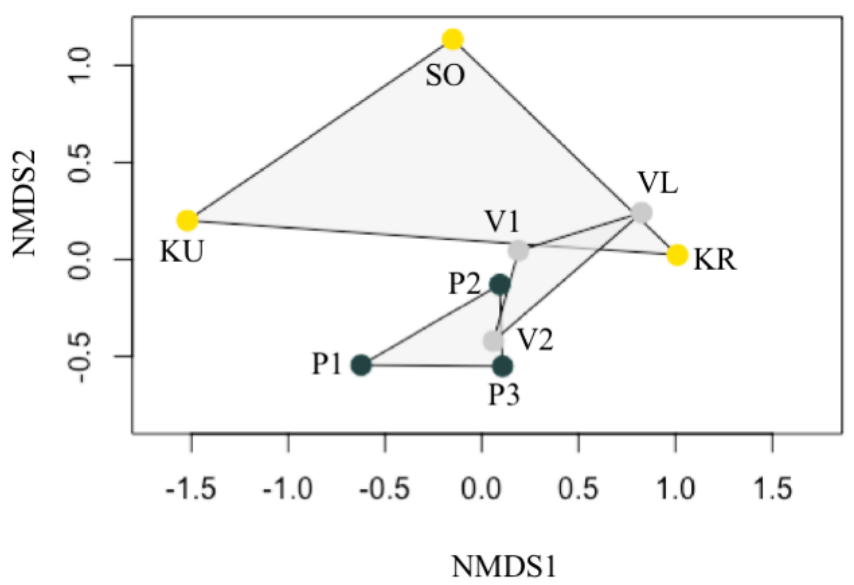

Figure 3. Non-metric multidimensional scaling of ant community assemblages. The circles represent the position of the individual plots in the ordination space, labeled with plot codes

(Table 1) and color-coded according to land use (blue-control, grey-perennial, yellowannual)

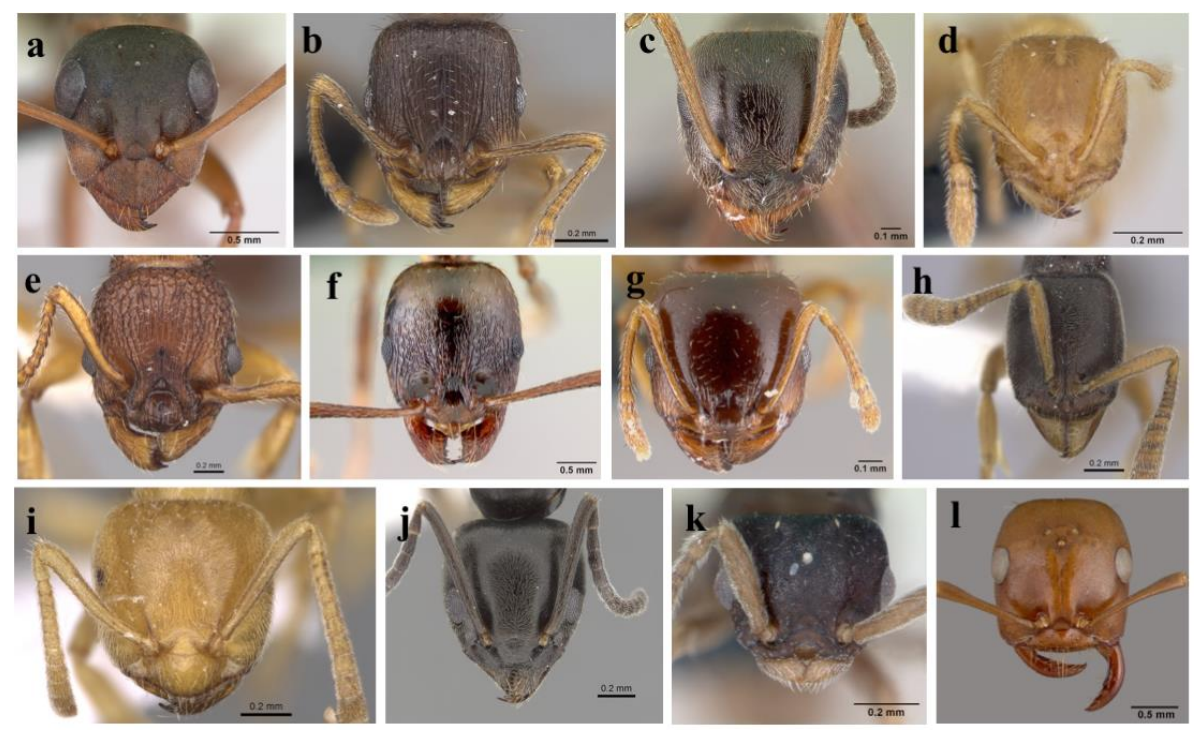

Figure 4. Images (head, frontal view) of sampled ant species. a Formica cunicularia (photo: antweb.org, CASENT0173175); b Tetramorium caespitum (photo: antweb.org, Flavia Esteves,

CASENT0919632); c Lasius niger (source: antweb.org, photo by Erin Prado,

CASENT0179897); d Solenopsis fugax (photo: antweb.org, CASENT0173147), e Myrmica scabrinodis (photo: antweb.org, Wade Lee, CASENT0922795); $f$ Aphaenogaster subterranea

(photo: antweb.org, Erin Prado, CASENT0179934); $\boldsymbol{g}$ Tetramorium semilaeve (photo: antweb.org, Erin Prado, CASENT0008637); $\boldsymbol{h}$ Ponera coarctata (photo: antweb.org, Will

Ericson, CASENT0249225); $\boldsymbol{i}$ Lasius myops (photo: antweb.org, Shannon Hartman, CASENT0906073); $\boldsymbol{j}$ Tapinoma erraticum (photo: antweb.org, Shannon Hartman, CASENT0249760); $\boldsymbol{k}$ Tetramorium atratulum (photo: antweb.org, CASENT0173077); $\boldsymbol{l}$ Polyergus rufescens (photo: antweb.org, CASENT0010688) 
The most represented subfamilies were Myrmicinae (6 species) and Formicinae (4 species), while Ponerinae and Dolichoderinae were both represented by a single species. The species with the highest abundance was Lasius niger (Linnaeus, 1758) (31\% of total ants collected, 115 individuals), which was present on all three land use types, and on 6 out of 9 plots. Three other species were present on all land use types and had a high abundance: Solenopsis fugax (17\% of total ants collected, 63 individuals), Tetramorium caespitum (Linnaeus, 1758) (18\%, 66 individuals), and Formica cunicularia (18\%, 67 individuals).

\section{Discussion}

\section{Effect of agricultural intensity on the ant fauna}

Results of our study show that agricultural practices associated with annual crops significantly decrease ant abundance. In contrast, the perennial crops support ant abundance slightly lower but similar to those in semi-natural habitats. Although no significant difference was found in the ant richness and diversity between the different land use types the plots with high agricultural intensity have the lowest ant richness and diversity. The community composition showed no clear separation by land use type, and most plots were dominated by the four common, generalist species. Our sample size was relatively small, so some of the observed results are likely to change with a larger data set. However, our results are concordant with previous findings that intensive agriculture has a negative impact on arthropod abundance and diversity (Sánchez-Bayo and Wyckhuys, 2019).

In particular, the decline of ants and other soil invertebrates has been associated with conventional tillage (Radford et al., 1995; Wilson-Rummenie et al., 1999; Sharley et al., 2008; Fernandes et al., 2018; Hevia et al., 2019), use of insecticides (Sánchez-Bayo and Wyckhuys, 2019), lack of nesting habitats due to habitat simplification, and changes in soil temperature and moisture (Kaspari et al., 2000; Armbrecht, 2004; Sanders et al., 2007; Graham et al., 2009; van Oudenhove et al., 2011). How strongly these different factors influence ant communities is not straightforward. For example, ant communities in olive orchards in Spain are found to be most affected by tillage practices (Hevia et al., 2019), while ant communities in French vineyards are strongly correlated with pesticide use (Masoni et al., 2017). The combination of those factors (soil disturbance by tillage, pesticide use, and habitat simplification) decreases the diversity and abundance of ants, which in turn changes the ecological balance of soil fauna and physical and chemical properties of soil.

Our study design does not allow us to test the influence of individual factors, such as insecticide and fertilizer use, because they both varied across the two agricultural land use systems. However, we hypothesize that the soil disturbance caused by tillage, which was conducted on annual plots only, and which was the most substantial difference in agricultural practice between annual and perennial plots, was the strongest individual factor that influenced ant richness, abundance, and diversity. Conventional tillage includes mechanical plowing, which causes physical disturbance of soil structure and soil biota, and causes water loss and erosion (Faulkner, 1943; Stinner, 2002). In contrast, conservation tillage practices do not include ploughing and retain a minimum of $30 \%$ cover of crop residue on the soil surface. Consequently, conservation tillage reduces soil erosion and water loss and supports diverse beneficial soil fauna (Blevins and Frye, 1993; Radford et al., 1995; Wilson-Rummenie et al., 1999; Stinner, 2002; Li, 
2018). The other likely factor that influenced ant fauna in our study is severe habitat homogenization in annual plots and consequently reduced resource availability. A future study that would manipulate the individual treatments, e.g. tillage only, needs to be conducted to determine the relative effects of these factors.

Research such as our study can provide scientific evidence for changes in future policies. In particular, we hope conservation tillage will gain support in both research and practice in Croatia in the near future. Knowing how land practices affect insect communities is especially important in the context of the coming changes in Common Agricultural Policy (CAP), one of the core EU policies. Historically, CAP was production oriented and promoted agricultural intensification. Since reform in 2013, it also addresses the environmental issues through the cross-compliance system, although this was recognized as a weak attempt by the conservation sector (Pe'er et al., 2014). Cross-compliance defines a set of rules for farmers in order to receive the subsidies, and some of them require practices that reduce soil erosion or enhance plant and animal biodiversity. In the future CAP reform, for the 2021-2027 period, currently under negotiations, three out of nine objectives are the environment or climate change oriented, and preserving carbon rich soils will be one of the new obligations (European Commission, 2018). The CAP provides a framework for national rural development policies in EU member states. In Croatia, cross-compliance legislation is in force since 2013 (Ministry of Agriculture, 2013), and the future CAP will certainly initiate its changes. Ideally, the new legislation should regulate conventional tillage, or at least publish the set of guidelines that emphasize the benefits of conservation tillage.

\section{The ant fauna of agricultural habitats}

The ant fauna of agricultural habitats in Zagreb is similar to ant fauna described in previous studies of open, disturbed, urban, and agricultural habitats (Seifert, 2007; Slipinski et al., 2012; Castracani et al., 2015; Masoni et al., 2017). It is composed of opportunistic, thermophilic, and disturbance-tolerant species such as T. caespitum, F. cunicularia, L. niger (Collingwood, 1979; Seifert, 2018). Most of the collected species have generalist diets but are primarily predators and scavengers (e.g., S. fugax, P. coarctata, T. caespitum). Predator diversity is a crucial natural mechanism for prevention of pest outbreaks, and ants are known to decrease pest populations by direct predation, chemically deterring pests, and by causing pests to drop from the plants (Way and Khoo, 1992; Perfecto and Snelling, 1995; Schmitz et al., 2000). In contrast, some ant species can be harmful by farming herbivorous insects (e.g., aphids and scale insects), but considering the number of beneficial effects, the net impact is shown to increase crop yield (Wielgoss et al., 2013).

All species collected in this study are primarily soil nesting, and their nest size varies from around 30 (P. coarctata) to 10000 workers (S. fugax). However, the majority of collected species have colonies of several hundred to 2000 workers (Taylor, 1967; Collingwood, 1979; Seifert and Schultz, 2009; Seifert, 2018). Soil nesting ant species contribute to maintaining and restoring soil quality (Lobry De Bruyn, 1999; Dorn, 2014; Sanabria et al., 2014). In particular, the impact of soil activities has been studied in two of the collected species. Studies in the USA found that L. niger move $885 \mathrm{~kg}$ of soil per hectare per year (Talbot, 1953; Lobry De Bruyn, 1999), F. cunicularia in China increases soil organic matter, total and available nitrogen, phosphorous, and potassium, electrical conductivity, and water content (Chen and Li, 2012). 
We sampled a rarely collected Polyergus rufescens on two plots: control plot (P2, meadow at the forest edge) and the perennial crop plot (V2, apple orchard). This is the only European species of genus Polyergus (Mori et al., 1991; Trager, 2013) and it is an obligate parasite of ant genus Formica (Castracani et al., 2008; Mori et al., 2010). Because of their specific life history ant species from genus Polyergus are of high conservation value (Social Insects Specialist Group, 1996; Trager, 2013). This species was last reported for Zagreb more than 70 years ago (Vogrin, 1955). Its host in the studied habitats is most likely Formica cunicularia, a common host of this species in Central Europe (Trager, 2013).

Another surprising find is obscure Tetramorium atratulum, inquiline social parasite, for the first time found in Croatia. This is a West Palearctic species that takes permanent residence in the nests of its host, mostly Tetramorium caespitum. Worker caste of T. atratulum is entirely missing, which is considered the extreme form of social parasitism in ants (Crawley, 1912; Buschinger, 2009; Seifert, 2018). Because of its complex life cycle, restricted gene flow, and low population size, this species is listed as Vulnerable (VU) on IUCN Red List (Social Insects Specialist Group, 1996). In our study area, the most likely host of this species is Tetramorium caespitum, one of the four most abundant ants in our study, and the most abundant species on the plot where T. atratulum queen was collected.

\section{Conclusion and recommendation for future study}

Our study has two main outcomes. First, it shows that ants have the potential for use as tools in agricultural management in Croatia, thanks to their abundance and sensitivity to land use. Second, it shows the importance of future studies in agricultural habitats, as they hold some of the vulnerable species important for insect conservation. Future research of ants of agricultural land in Croatia should identify the particular ecological and physiological factors that support a diverse and abundant ant community. This was previously investigated in other countries (Armbrecht, 2004; Frizzo and Vasconcelos, 2013), but needs to be tested in regionally specific environmental conditions. For example, future studies should compare the ant communities of different levels of tillage (no-tillage, reduced, standard and deep), in different regions of Croatia. Knowing which agricultural practices are detrimental or beneficial to ants can inform sustainable management planning and increase crop yields (Evans et al., 2011; Wielgoss et al., 2013; Gras et al., 2016; Shukla et al., 2016). Another important direction for future research is identifying the ant species that can be bioindicators of soil quality and of High Nature Value (HNV) farming, like those already successfully developed for other regions (Perfecto and Snelling, 1995; Philpott and Ambrecht, 2006; Sanabria et al., 2014). This would require a comparative study of ants and physical and biochemical soil properties, across land use gradient. Ants are thermophilic, and successful in dry climates, unlike some other taxa important for soil quality (e.g., earthworms). Considering the effects of climate change, which among other hazards predict increased drought and higher temperatures (Myles et al., 2018), the development of ants as a tool for sustainable farming is urgently needed in Croatia.

Acknowledgments. Three anonymous reviewers provided comments and suggestions that improved this manuscript. We are indebted to Tanja Mihinjač, Marko Rajković, and Josip Živković for their help with fieldwork. Ivana Ilijaš was available for useful discussions about CAP and cross-compliance. Jelena 
Bujan provided statistical advice, commented on the manuscript, and helped with lists. This study would not be possible if ants are not such interesting and resilient organisms that provide perpetual research inspiration.

\section{REFERENCES}

[1] Agosti, D., Collingwood, C. A. (1987): A provisional list of the Balkan with a list to the worker caste. II. Key to the worker caste, including the European species without the Iberian. - Mitteilungen der Schweizerischen Entomologischen Gesellschaft 60: 261-293.

[2] Agosti, D., Majer, J. D., Alonso, L. E., Schultz, T. R. (2000): Ants: Standard methods for measuring and monitoring biodiversity. - Smithsonian Institution Press.

[3] Andersen, A. N., Hoffmann, B. D., Müller, W. J., Griffiths, A. D. (2002): Using ants as bioindicators in land management: Simplifying assessment of ant community responses. - Journal of Applied Ecology 39: 8-17.

[4] Armbrecht, I. (2004): Enigmatic biodiversity correlations: ant diversity responds to diverse resources. - Science 304: 284-286.

[5] Blevins, R. L., Frye, W. W. (1993): Conservation tillage: An ecological approach to soil management. - Advances in Agronomy (USA).

[6] Borgelt, A., New, T. R. (2006): Pitfall trapping for ants (Hymenoptera, Formicidae) in mesic Australia: what is the best trapping period? - Journal of Insect Conservation 10: 75-77.

[7] Bračko, G. (2006): Review of the ant fauna (Hymenoptera: Formicidae) of Croatia. Acta Entomologica Slovenica 14: 131-156.

[8] Buschinger, A. (2009): Social parasitism among ants: A review (Hymenoptera: Formicidae). - Myrmecological News 12: 219-235.

[9] Castracani, C., Maienza, A., Grasso, D. A., Genesio, L., Malcevschi, A., Miglietta, F., Vaccari, F. P., Mori, A. (2015): Biochar-macrofauna interplay: Searching for new bioindicators. - Science of the Total Environment 536: 449-456.

[10] Castracani, C., Mori, A. (2006): The role of permanent grasslands on ant community structure: ants (Hymenoptera: Formicidae) as ecological indicators in the agroecosystems of the Taro River Regional Park (Italy). - Myrmecologische Nachrichten 9: 47-54.

[11] Castracani, C., Tamarri, V., Grasso, D. A., Le Moli, F., Palla, G., Millar, J. G., Francke, W., Mori, A. (2008): Chemical communication in mating behaviour of the slave-making ant Polyergus rufescens (Hymenoptera, Formicidae): 3-ethyl-4-methylpentanol as a critical component of the queen sex pheromone. - Insectes Sociaux 55: 137-143.

[12] Chen, Y.-W., Li, X.-R. (2012): Spatio-temporal distribution of nests and influence of ant (Formica cunicularia Lat.) activity on soil property and seed bank after revegetation in the Tengger desert. - Arid Land Research and Management 26: 365-378.

[13] Collingwood, C. A. (1979): The Formicidae (Hymenoptera) of Fennoscandia and Denmark. - Scandinavian Science Press 8: 1-174.

[14] Crawley, W. C. (1912): Anergates atratulus, Schenk., a British ant, and the acceptance of a queen by Tetramorium caespitum, L. - Entomologist's Record and Journal of Variation 24: 218-219.

[15] Dorn, R. I. (2014): Ants as a powerful biotic agent of olivine and plagioclase dissolution. - Geology 42: 771-774.

[16] Dufrêne, M., Legendre, P. (1997): Species assemblages and indicator species: The need for a flexible asymmetrical approach. - Ecological Monographs 67: 345-366.

[17] European Commission (2018): EU Budget: the Common Agricultural Policy beyond 2020.

[18] Evans, T. A., Dawes, T. Z., Ward, P. R., Lo, N. (2011): Ants and termites increase crop yield in a dry climate. - Nature Communications 2: 262. 
[19] Farji-Brener, A. G., Werenkraut, V. (2017): The effects of ant nests on soil fertility and plant performance: a meta-analysis. - Journal of Animal Ecology 86: 866-877.

[20] Faulkner, E. H. (1943): Plowman's folly. - LWW 56(5): 1-394.

[21] Fernandes, W. D., Lange, D., Pereira, J. M., Raizer, J. (2018): Ant community in neotropical agrosystems: A four-year study in conventional and no-tillage systems. Sociobiology 65: 130-137.

[22] Frizzo, T. L. M., Vasconcelos, H. L. (2013): The potential role of scattered trees for ant conservation in an agriculturally dominated neotropical landscape. - Biotropica 45: 644651.

[23] Frouz, J., Jilková, V. (2008): The effect of ants on soil properties and processes (Hymenoptera: Formicidae). - Myrmecological News 11: 191-199.

[24] Furlan, L., Vasileiadis, V. P., Chiarini, F., Huiting, H., Leskovšek, R., Razinger, J., Holb, I. J., Sartori, E., Urek, G., Verschwele, A., Benvegnù, I., Sattin, M. (2017): Risk assessment of soil-pest damage to grain maize in Europe within the framework of Integrated Pest Management. - Crop Protection 97: 52-59.

[25] German, R. N., Thompson, C. E., Benton, T. G. (2017): Relationships among multiple aspects of agriculture's environmental impact and productivity: a meta-analysis to guide sustainable agriculture. - Biological Reviews 92: 716-738.

[26] Graham, J. H., Krzysik, A. J., Kovacic, D. A., Duda, J. J., Freeman, D. C., Emlen, J. M., Zak, J. C., Long, W. R., Wallace, M. P., Chamberlin-Graham, C., Nutter, J. P., Balbach, H. E. (2009): Species richness, equitability, and abundance of ants in disturbed landscapes. - Ecological Indicators 9: 866-877.

[27] Gras, P., Tscharntke, T., Maas, B., Tjoa, A., Hafsah, A., Clough, Y. (2016): How ants, birds and bats affect crop yield along shade gradients in tropical cacao agroforestry. Journal of Applied Ecology 53: 953-963.

[28] Hevia, V., Ortega, J., Azcárate, F. M., López, C. A., González, J. A. (2019): Exploring the effect of soil management intensity on taxonomic and functional diversity of ants in Mediterranean olive groves. - Agricultural and Forest Entomology 21: 109-118.

[29] Hobbs, P. R., Sayre, K., Gupta, R. (2008): The role of conservation agriculture in sustainable agriculture. - Philosophical Transactions of the Royal Society B: Biological Sciences 363: 543-555.

[30] Holldobler, B., Wilson, E. O. (1990): The Ants. - Springer-Verlag Berlin Heidelberg.

[31] Ješovnik, A., Bujan, J., Bračko, G. (2011): One genus and three species of ants (Hymenopter: Formicidae) new for Croatia. - Entomologia Croatica 15: 113-122.

[32] Ješovnik, A., Pečarevič, M. (2018): The importance of invertebrates in conservation: the case of the ants. - Book of Abstracts of the 13th Croatian Biological Congress: 126-127.

[33] Kaspari, M., O’Donnell, S., Kercher, J. R. (2000): Energy, density, and constraints to species richness: ant assemblages along a productivity gradient. - The American Naturalist 155: 280-293.

[34] Lavelle, P., Decaëns, T., Aubert, M., Barot, S., Blouin, M., Bureau, F., Margerie, P., Mora, P., Rossi, J. P. (2006): Soil invertebrates and ecosystem services. - European Journal of Soil Biology 42: 3-15.

[35] Lemić, D., Čačija, M., Virić Gašparić, H., Drmić, Z., Bažok, R., Pajač Živković, I. (2017): The ground beetle (Coleoptera: Carabidae) community in an intensively managed agricultural landscape. - Applied Ecology and Environmental Research 15: 661-674.

[36] Lemić, D., Virić Gašparić, H., Petrak, I., Graša, Ž., Bažok, R. (2016): Utjecaj četverogodišnjeg plodoreda na obnovu korisne faune člankonožaca površinskog sloja tla. - Journal of Central European Agriculture 17: 1346-1359.

[37] Li, J. (2018): Analysis of soil fertility and biological changes under long-term conservation tillage. - Asian agricultural research 10: 62-65.

[38] Lobry De Bruyn, L. A. (1999): Ants as bioindicators of soil function in rural environments. - Agriculture, Ecosystems and Environment 74: 425-441. 
[39] Masoni, A., Frizzi, F., Brühl, C., Zocchi, N., Palchetti, E., Chelazzi, G., Santini, G. (2017): Management matters: A comparison of ant assemblages in organic and conventional vineyards. - Agriculture, Ecosystems \& Environment 246: 175-183.

[40] Ministry of Agriculture (2018): Regulation on cross-compliance. - Official Gazette 32/2013, 45/2016, 26/2018, 84/2018.

[41] Mori, A., Grasso, D. A., Le Moli, F. (1991): Notes on the biology of the slave-making ant Polyergus rufescens Latr. (Hymenoptera Formicidae) in the field. - Ethology Ecology \& Evolution 3: 81-85.

[42] Mori, A., Grasso, D. A., Moli, F. (2010): Eco-ethological study on raiding behaviour of the European Amazon ant, Polyergus rufescens Latr. (Hymenoptera: Formicidae). Ethology 88: 46-62.

[43] Myers, S. S., Zanobetti, A., Kloog, I., Huybers, P., Leakey, A. D. B., Bloom, A. J., Carlisle, E., Dietterich, L. H., Fitzgerald, G., Hasegawa, T., Holbrook, N. M., Nelson, R. L., Ottman, M. J., Raboy, V., Sakai, H., Sartor, K. A., Schwartz, J., Seneweera, S., Tausz, M., Usui, Y. (2014): Increasing CO2 threatens human nutrition. - Nature 510: 139-142.

[44] Myles, A., Mustafa, B., Yang, C., de Coninck, H. (2018): Global Warming of $1.5^{\circ} \mathrm{C}$. Summary for Policymakers. - IPPC.

[45] Ottonetti, L., Tucci, L., Santini, G. (2006): Recolonization patterns of ants in a rehabilitated lignite mine in Central Italy: Potential for the use of Mediterranean ants as indicators of restoration processes. - Restoration Ecology 14: 60-66.

[46] Pajač Živković, I., Barić, B., Kos, T., Suda, H., Jemrić, T., Fruk, M., Lemić, D. (2016): The ground beetle fauna (Coleoptera) of apple orchard in Croatia. - Agriculturae Conspectus Scientificus 81: 103-107.

[47] Pe'er, G., Dicks, L. V., Visconti, P., Arlettaz, R., Baldi, A., Benton, T. G., Collins, S., Dieterich, M., Gregory, R. D., Hartig, F., Henle, K., Hobson, P. R., Kleijn, D., Neumann, R. K., Robijns, T., Schmidt, J., Shwartz, A., Sutherland, W. J., Turbe, A., Wulf, F., Scott, A. V. (2014): EU agricultural reform fails on biodiversity. - Science 344: 1090-1092.

[48] Perfecto, I., Snelling, R. (1995): Biodiversity and the transformation of a tropical agroecosystem: Ants in coffee plantations. - Ecological Applications 5: 1084-1097.

[49] Philpott, S. M., Ambrecht, I. (2006): Biodiversity in tropical agroforests and the ecological role of ants and ant diversity in predatory function. - Ecological Entomology 31: 369-377.

[50] Piao, S., Ciais, P., Huang, Y., Shen, Z., Peng, S., Li, J., Zhou, L., Liu, H., Ma, Y., Ding, Y., Friedlingstein, P., Liu, C., Tan, K., Yu, Y., Zhang, T., Fang, J. (2010): The impacts of climate change on water resources and agriculture in China. - Nature 467: 43-51.

[51] Power, A. G. (2010): Ecosystem services and agriculture: tradeoffs and synergies. Philosophical Transactions of the Royal Society B: Biological Sciences 365: 2959-2971.

[52] R Development Core Team (2014): R: A language and environment for statistical computing. - R Foundation for Statistical Computing, Vienna, Austria.

[53] Radford, B., Key, A., Robertson, L., Thomas, G. (1995): Conservation tillage increases in soil water storage, soil animal populations, grain yield, and response to fertiliser in the semi-arid subtropics. - Australian Journal of Experimental Agriculture 35: 223.

[54] Read, J. L., Andersen, A. N. (2000): The value of ants as early warning bioindicators: responses to pulsed cattle grazing at an Australian arid zone locality. - Journal of Arid Environments 45: 231-251.

[55] Reganold, J. P., Wachter, J. M. (2016): Organic agriculture in the twenty-first century. Nature Plants 2: 15221.

[56] Ribas, C. R., Schmidt, F. A., Solar, R. R., Campos, R. B., Valentim, C. L., Schoereder, J. H. (2012): Ants as indicators of the success of rehabilitation efforts in deposits of gold mining tailings. - Restoration Ecology 20(6): 712-720.

[57] Sanabria, C., Lavelle, P., Fonte, S. J. (2014): Ants as indicators of soil-based ecosystem services in agroecosystems of the Colombian Llanos. - Applied Soil Ecology 84: 24-30. 
[58] Sánchez-Bayo, F., Wyckhuys, K. A. G. (2019): Worldwide decline of the entomofauna: A review of its drivers. - Biological Conservation 232: 8-27.

[59] Sanders, N. J., Lessard, J. P., Fitzpatrick, M. C., Dunn, R. R. (2007): Temperature, but not productivity or geometry, predicts elevational diversity gradients in ants across spatial grains. - Global Ecology and Biogeography 16: 640-649.

[60] Schmitz, O. J., Hambäck, P. A., Beckerman, A. P. (2000): Trophic cascades in terrestrial systems: A review of the effects of carnivore removals on plants. - The American Naturalist 155(2): 141-153.

[61] Schweiger, O., Maelfait, J. P., Van Wingerden, W., Hendrickx, F., Billeter, R., Speelmans, M., Augenstein, I., Aukema, B., Aviron, S., Bailey, D., Bukacek, R., Burel, F., Diekotter, T., Dirksen, J., Frenzel, M., Herzog, F., Liira, J., Roubalova, M., Bugter, R. (2005): Quantifying the impact of environmental factors on arthropod communities in agricultural landscapes across organizational levels and spatial scales. - Journal of Applied Ecology 42: 1129-1139.

[62] Seifert, B. (2007): Die Ameisen Mittel- und Nordeuropas. - Lutra Verlags- und Vertriebsgesellschaft.

[63] Seifert, B. (2018): The ants of central and northern Europe. - Lutra Verlags und Vertriebsgesellschaft.

[64] Seifert, B., Schultz, R. (2009): A taxonomic revision of the Formica rufibarbis Fabricius, 1793 group (Hymenoptera: Formicidae). - Myrmecological News 12: 255-272.

[65] Sharley, D. J., Hoffmann, A. A., Thomson, L. J. (2008): The effects of soil tillage on beneficial invertebrates within the vineyard. - Agricultural and Forest Entomology 10: 233-243.

[66] Shukla, R. K., Singh, H., Rastogi, N. (2016): How effective are disturbance - tolerant, agroecosystem - nesting ant species in improving soil fertility and crop yield? - Applied Soil Ecology 108: 156-164.

[67] Skinner, J. A., Lewis, K. A., Bardon, K. S., Tucker, P., Catt, J. A., Chambers, B. J. (1997): An overview of the environmental impact of agriculture in the U.K. - Journal of Environmental Management 50: 111-128.

[68] Slipinski, P., Zmihorski, M., Czezhowski, W. (2012): Species diversity and nestedness of ant assemblages in an urban environment. - European Journal of Entomology 109: 197206.

[69] Social Insects Specialist Group (1996): The IUCN Red List of Threatened Species.

[70] Stadler, B., Schramm, A., Kalbitz, K. (2006): Ant-mediated effects on spruce litter decomposition, solution chemistry, and microbial activity. - Soil Biology and Biochemistry 38: 561-572.

[71] Stinner, B. (2002): Arthropods and other invertebrates in conservation-tillage agriculture. - Annual Review of Entomology 35: 299-318.

[72] Stoate, C., Boatman, N., Borralho, R., Carvalho, C. R., de Snoo, G. R., Eden, P. (2001): Ecological impacts of arable intensification in Europe. - Journal of Environmental Management 63: 337-365.

[73] Talbot, M. (1953): Ants of an old-field community on the Edwin S. George Reserve, Livingston County, Michigan. - Contributions to Laboratory of Vertebrate Biology, University of Michigan 69: 1-9.

[74] Taylor, R. W. (1967): A monographic revision of the ant genus Ponera Latreille (Hymenoptera: Formicidae). - Pacific Insects Monographs 13: 1-112.

[75] Trager, J. C. (2013): Global revision of the dulotic ant genus Polyergus (Hymenoptera: Formicidae, Formicini). - Zootaxa 3722: 501-548.

[76] Underwood, E. C., Fisher, B. L. (2006): The role of ants in conservation monitoring: If, when, and how. - Biological Conservation 132: 166-182.

[77] Van Oudenhove, L., Billoir, E., Boulay, R., Bernstein, C., Cerdá, X. (2011): Temperature limits trail following behaviour through pheromone decay in ants. - Naturwissenschaften 98: 1009-1017. 
[78] Vogrin, V. (1955): Prilog fauni Hymenoptera - Aculeata Jugoslavije. - Zaštita Bilja 31: $1-74$.

[79] Wagner, D., Jones, J. B., Gordon, D. M. (2004): Development of harvester ant colonies alters soil chemistry. - Soil Biology and Biochemistry 36: 797-804.

[80] Wagner, H. C., Arthofer, W., Seifert, B., Muster, C., Steiner, F. M., Schlick-Steiner, B. C., (2017): Light at the end of the tunnel: Integrative taxonomy delimits cryptic species in the Tetramorium caespitum complex (Hymenoptera: Formicidae). - Myrmecological News 25: 95-129.

[81] Way, M. J., Khoo, K. C. (1992): Role of ants in pest management. - Annual Review of Entomology 37: 479-503.

[82] Wielgoss, A., Tscharntke, T., Rumede, A., Fiala, B., Seidel, H., Shahabuddin, S., Clough, Y. (2013): Interaction complexity matters: disentangling services and disservices of ant communities driving yield in tropical agroecosystems. - Proceedings of the Royal Society B: Biological Sciences 281.

[83] Wilson-Rummenie, A. C., Radford, B. J., Robertson, L. N., Simpson, G. B., Bell, K. L. (1999): Reduced tillage increases population density of soil macrofauna in a semiarid environment in Central Queensland. - Environmental Entomology 28: 163-172.

[84] Zaninović, K., Gajić-Capka, M., Perčec Tadić, M. (2008): Klimatski atlas Hrvatske / Climate atlas of Croatia 1961-1990, 1971-2000. - Državni hidrometerološki zavod. 